\title{
明治初期の内国勧業博覧会における会場デザインの思想
}

\section{Spatial Design Concepts of National Exhibition in the Early Years of Meiji Era}

小野良平*

Ryohei ONO

\begin{abstract}
摘要 : 博覧会は一つの都市的虚構ということができ, 博覧会の開催されたそれぞれの時代は, 建築物 や工作物のデザインばかりでなく会場計画全体に敏感に反映されるものと考えることができる。本稿 では, 明治期の急速な近代化の中で国家が主導的に進めた内国勧業博筧会の会場計画における空間デ ザインの面に着目し，わが国の近代化のなかでの外部空間デザイン思想の一つの様相を探ることを試 みた。その中で近代の知覚の変革を啓蒙しようとする近代西欧的空間と博覧会の祝祭性を演出する伝 統的空間とがともに計画者によって意識的に設定されていたこと等が明らかになった。
\end{abstract}

\section{1.はじめに}

明治 10(1877）年 8月，明治政府すなわち内務卿大久保利通は, 同郷の西郷隆盛率いる薩摩軍との間で西南戦争を行っている最中, 東京・上野において第 1 回内国勧業博覧会を開催した。その会場 は, 皮肉にも西郷ら官軍が, 立てこもる彰義隊を撃ち破った東呫 山寛永寺の焼失跡地であったが，そこは同時に前年の明治 9 年に 開園したばかりの上野公園の敷地でああった。というよりも博覧 会を見込んで公園は開園されたといえる。1) 上野公園の成立時の

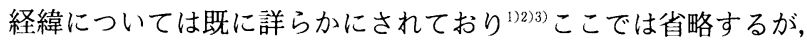
上野公園は内務省の所管 (のち明治 14 年には農商務省, 19 年に は宮内省に移管）という国家を背負った特殊な位置づけの中で, 博覧会の会場として繰り返し使用されるとともに博物館を中心に 数々の文化施設を加え, 従来の花見の名所性をも保ちながら娛楽 性と文化性を合わせ持った独特のゾーンを形成して行った。こう したトータルな流れの中での上野公園の形成における博覧会との 関連についても，これまでに土地の文脈に着目した考察がなされ ている。奋) しかしながら公園の初期段階から現れた博覧会自身の 姿に関しては，具体的にどのような空間であったかという点につ いては未だ不明な部分が多くイメージがつかめない。

明治の博覧会は，既に欧米で開催されていた万国博覧会を範と する, 富国強兵, 殖産興業の推進役として盛んに開催された文明 開化の一つのキーワードであった。万国博覧会を代表に博覧会の 誕生は, 近年社会史的には視覚の近代化という観点でも捉えられ ており, ${ }^{6)}$ それは展示品の陳列手法等の演出法にも特徴的に現れ ていることからあ指摘されている。そ ${ }^{7}$ その意味で博覧会場全体の プランも近代の視覚装置であったといえ，本稿は明治前期の博覧 会場の計画を対象として，その空間計画に着目してそこに込めら れた意図や，意図せずして現れた特質を探ることを目的とする。

直接これらの博覧会に係わる既往の研究としては, 第 1 回内国 勧業博覧会に関して建築史的な考察を行ったあの ${ }^{8)}$ がある。また 公園計画との関係での研究としては, 明治後期以降の博覧会と公 園の開発に関する研究 ${ }^{9)}$ や, 公園デザインの系譜の一部として博 覧会を捉えた研究10)等もある。本研究はこれら既往の研究を踏ま え, 政府主催で開催された上野公園での 3 回（明治 10,14,23 年） の内国勧業博覧会を対象とし，特に明治政府が初めて主催した第 1 回に重点を置いて考察を進める。
2. 第 1 回内国勧業博覧会（明治 10, 1877 年）

博覧会全般にわたる経緯等については他書 ${ }^{11)}$ に譲るとして，第 1 回内国勧業博覧会（以下内国博とする）の会場は，その資料之 して図ー 1 の銅版画に描かれた姿をむって比較的良く知られてい る。その絵画としての夕ッチもさることながら, 洋館を中心とし た対称型の陳列館の配置や中央の西洋風庭園等から非常に西欧的 空間であったことは一応は推測される。しかしながらこの絵は現 実の博覧会場を写し取ったものではなく，今でいう計画段階での 完成イメージパースであった。それは博覧会開催前に作成された

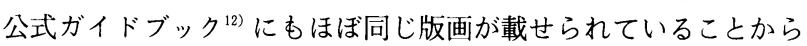
判断できる(正確には細部が若干異なる)。この案内書には改訂 版 ${ }^{13)}$ がありそこには平面図（図－2）が追加されている。この平 面図によれば銅版画と同様の建物配置や，対称型に園路を取り入 れた整形式の庭園が確かに計画されている。しかしそれよりも直 ちに気がつくのは，銅版画に描かれていない，手前に表門までまっ すぐ乫き進む通りと, その両側に建物が並んで街並み状になった 部分である。案内によればこれらは「博覧会場付属売物店」, す なわち売店でその敷地は博覧会場外であるらしい。この売店街は 非常に興味樑く検討を要する。

（1）会場付属売物店

この売物店の意図するところは開催の前年に作成された博覧会 規則に示されている。

（前略）茲に売店を取建つることを許し其店中にて場上に列し あのと同し品物を売らしめ衆人の便利を図る（中略）

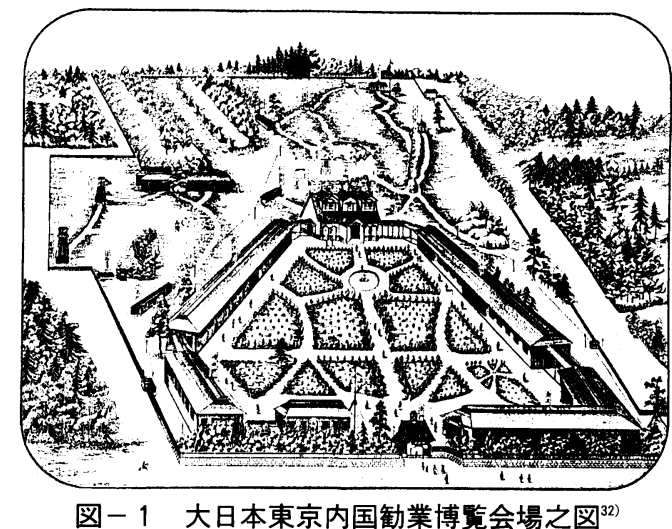

図-1 大日本東京内国勧業博覧会場之図 ${ }^{32}$ 
第一条 場上に列しものと同し品柄のあの数個ありて直に売別 んと思ふ者は博覧会場外公園にて別に一区の地を無税 貸与ふへし 第二条 売店なりとも本局官員の差図を 受け見苦しからさる様建築すへし

第三条 建築其他売店に拘はる一切の入用は自費なるへし

（中略）第六条 売店を取建んと思ふ者八所用の地坪家作等を取 調べ絵図を添て（中略）申出へし ${ }^{14)}$

つまり売店街は会場外の自費建築とはいえ, 主催者側で大変意 図的に計画され統制がかけられていたことがわかる。では実際ど んなむのが売られたのだろうか。平面図に各户ごとに細かく記載 された品目をみると出品県毎に食品, 日用品, 雑貨類等の特産品 が並んでいる。つまり全国名産展, 門前市の様子である。一方こ の売店の並ぶ通りは馬車道（約 7 間）とその両側の人道（各約 2 間）とからなる,つまり両側歩道の歩車分離道であった。これは 銀座棟瓦街（明治 6 年）等に現れた近代の街路構成である。洋館 之西洋庭園の前面にのびる近代的街路と縁日的空間....ここはど のように解釈すればよいのだろうか。

その手がかりは 4 年前のウィーン万国博覧会 (1873, 明治 6 年) に見いだすことができる。この万博は日本政府が初めて本格的に 参加し, 国内で勧業博覧会を開く契機となった意義深い万博であ るが，日本からは，建物内の通常の展示とは別に，「日本社園」 と呼ばれる小さな神社を中心とした屋外型の展示スペースが出展 された。 ${ }^{15)}$ (図一 - ・4 ) 参加した「博覧会事務官」による筆記報 告によると, 本館とは別に会場内に並ぶ各国の料理店, 産物店,

茶店等を描いたあと次のように記している。

（前略）吾國にてもいささかこれらの用意あり正堂より南の方

(中略) 地勢よろしけれはここを千三百坪ほど圍ひこみ入口に 白木の鳥居をたて奥に白木の神社一宇をつくり（中略）左りの 方には神楽堂をたて前には小さき池を穿ち錦魚小亀なとを放ち 日本風の反り橋に欄干のつきたるを掛けわたし鳥居より宮まて の道の両側には小さき店三軒つつたて例年の神祭りのときの社 前の市になそらへ國の名産漆器陶器銅器織物茶烟草なとの類よ り小児の玩ものにいたるまてここにて売らしむ (後略) ${ }^{16}$

まさに賑わいをつくるための縁日的空間が意図されていたので ある。これは明らかに江戸以来の開帳, 見せ物の系譜を受け継ぐ

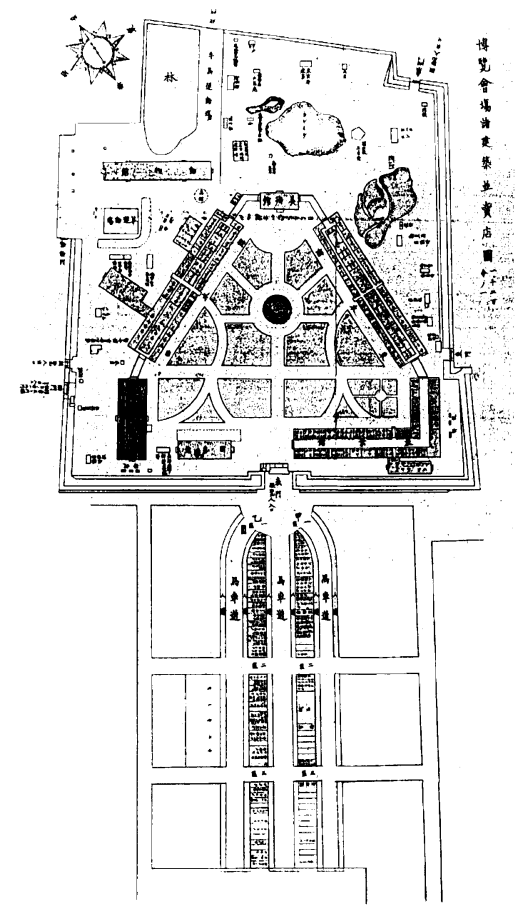

図-2 第一回内国勧業博覧会平面図 ${ }^{(3)}$

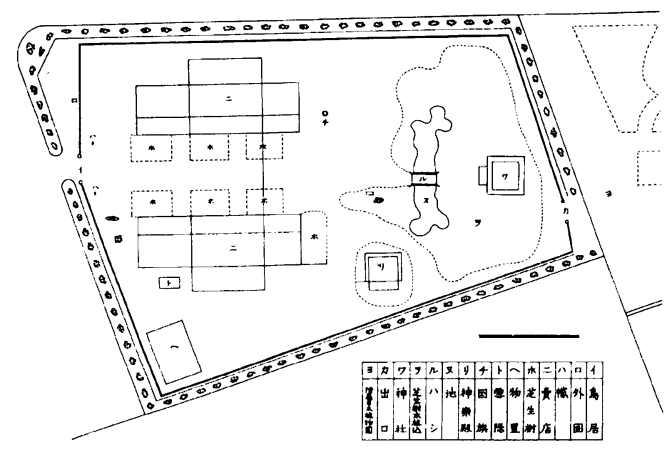

図一－ウィーン博日本社園平面図 ${ }^{15}$

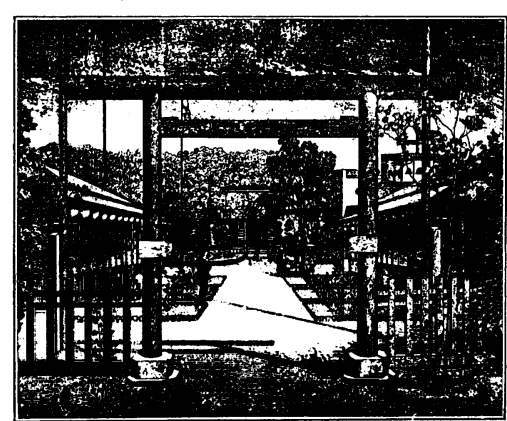

図-4 ウィーン博日本社園 ${ }^{15)}$
あのであり，これと同様の考え方が第 1 回内国博の付属売物店に も持ち込まれたことは間違いない。それではなぜ売店街は「会場 外」に位置づけられたのだろうか。考えられる理由の一つとして は，事業費を節約するという切実な問題むあったと思われる ${ }^{17)}$ が, 「会場内」を見ることによって別な側面が見えてくる。

\section{（2）会場内陳列館の配置計画}

図一2 の会場計画で特徴的なことは，既に触れたように正面の 美術館を扇の要とした軸性のある対称型の陳列館の配置計画と, その建物に囲まれるように配された中央に噴水を持つ庭園である。 東西両側に斜めに配置された本館をはじめ, 機械館, 農業館, 園 芸館, 動物館等の各陳列館は基本的に木造の仮設的建築物であっ たが，美術館のみは煉瓦造の建築物として博覧会後む保存するこ とが想定されていた。その設計は工部省営繥局の日本人の手にな

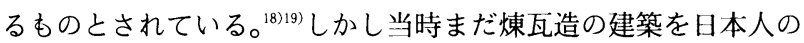
みで設計できたとは考えにくく，工部省の御雇外国人建築家であっ たアンダーソン, カペレッティ, ボアンウィル等 ${ }^{20)}$ の建築家達の 関与があったことが推測される。本稿は博覧会建築の建築史的考 察を行うものではないが, 第 1 回内国博の会場計画には, 上記の ボアンゥィルが設計した工部大学校講堂 (明治 10 年 6 月竣工) との関わりを見いだすことができる。工部大学校の当初計画案は, 講堂を要としてコの字状に校舎を配置し, 中央に庭園を持つ, ${ }^{21)}$ 内国博の会場計画によく似たプランであった。（図ー5 ) 現実に は講堂と片側のウイングのみに終わったが, 同様の構成は設計者 不明ながら明治 7 年頃の竣工とされる東京裁判所 ${ }^{22}$ （図一-6）に あ見ることができる。もちろん形態的類似性からだけでこれらの 建築と博覧会の会場構成を結びつけることは性急に過ぎるし，工 部大学校や東京裁判所の矩形の配置と博覧会の美術館を挟んだ斜 めの配置は異なるが, 当時の博覧会に与えられた意味を考えるこ とでやはり両者の関係性の強さは確証を得ることができる。

先の博覧会の案内書には, 冒頭に「観者注意」という入場者心 得が記されている。日く

内國勧業博覧会の本旨たる工藝の進歩を助け物産貿易の開かし むるにあり徒に戯玩の場を設けて遊覧の具となすにあらざるなり 博覧会の効益を約言せば践渉の労なく輙く一場に就て全国の萬品 を周覧して以て其優劣異同を判別すべくまた各人工藝上の実験と 其妙処とを併せて一時に 領収する是なり（中略）

物品の優劣を定むるは 審査官の本務にして不日 応に一定の公評あるへし といへとも凡そ会場に入 る者は人々審查官の気象 あるを要す (中略) 斯の 如く仔細に観察し来らは 凡そ万象の眼に触る皆知 識を長するの媒となり一 物の前に横たはる悉く見 聞を広むるの具たらさるなし(後略) ${ }^{23)}$

明治政府の意図した博覧会は遊覧の場 ではなく, 判別, 審査, 観察, 知識といっ た近代にふさわしい認識の眼を国民に求 める教化的，啓蒙的なむのであった。そ のような空間の計画に際して, 同様な知 性の働きの場として設計された大学校や 裁判所の空間配置に範がとられた可能性 は, 同じ工部省の関与を考えても高い。 新しい時代の博覧会からは, 博覧会と類 似の存在であった江戸以来の「見せ物」 
の娛楽的性格を払拭する必要があった。新しい近代の「意味付け」 が会場計画そのあのにあ必要だったのである。それゆえに縁日的 空間は「会場外」に置かなければならなかった。先の銅版画から 会場外の描写が完全に排除されていたのむこの理由によって理解 することができる。この銅版画は明治政府が国民に示したプロパ ガンダであったのだから。

しかし興味深いのはそれでもあくまで売店街は「計画」された ことで，確かに博覧会本体とは敷地上む体制上も分離されていた のだが，明らかに博覧会の「門前」の縁日は計画者が主導的に創 りだしたものだったのである。近代的な認識の眼を国民に啓蒙す ることを建前としながらあ，博覧会の持つ祝祭的側面の必要性が 見抜かれていた。その必要性は直接的には，すでに見たとおりウィー ン万博から体得してきたことであろうし, 背景としては例えば江 戸の社寺と門前街の関係に見られたような都市の両義性・...とれ は博覧会の場となる寛永寺と上野の関係においてもそうだった・... が継承されたともいえる。つまり計画者は博覧会が都市の虚構で あることを当初から認識して相互補完的空間をあらかじめ準備し た。こうして近代=西欧的=公式 =会場内と, 前近代 =江戸的 $=$ 非公式 $=$ 会場外之の共存によって構築される空間が第 1 回内国博 のマスタープランとなったのである。

\section{（3）近代と伝統の交錯}

以上のように博覧会場内は「近代」の空間たるべく西欧的空間 の創造が目指されたわけであるが，もう少し個々のデザインをみ ると実際どのような空間であったろうか。陳列館の配置を良く見 ると，全体的には対称型の配置に見えるが，表門を入ると右側に 農業館の入り口が控えており, 動線は自然と農業館へ流れるよう にできている。さらに各館は動物館と園芸館を除いて渡り廊下で つながれており，入場者は農業館から会場内を左廻りに一巡して 行くような会場構成となっている。案内書では見学順序は特に定 めておらずむしろどこから見ても良いことを強調している 実際の空間は逆にお遍路型あるいは名所双六型というべき一筆書 きの動線の伝統的なスタイルとなっている。またこの会場の表門 とされているのは，焼失した寛永寺の数少ない焼け残りである本 坊の中門をそのまま会場のエントランスゲートとして使用した, 屋根の上に時計台を載せた奇妙なむのであったが，その門は戊辰
戦争の弾痕をのこしたままであったという。25)

さらに中央部の庭園に眼を移す。複数の絵図などから比較検討 してみると平面図や銅版画に見られる幾何学的な園路と緑地の地 割は確かに実現していたようである。設計者は判らないが，既に 触れたように工部省によって建築と一体に設計された可能性は高 く，芝らしき地被に灌木を規則的に植え込んだものであることは 窺える。面白いことは南西の一角に松と思われる巨木が一本描か れていることである。（図-1及び図－7）この松は第 2 回内国 博まで残されておりこのときは樹下に精養軒が茶店を出している。 それほど立派な樹木が残っていたということであろうが，あくま で西欧風の空間を目指した会場の庭園内に残されたこの樹木は, その樹種といい, シンメトリーから外れた位置といい，この会場 に表れた近代と伝統のデザインの交錯を象徴的に示している。

3 、第 2 回・ 3 回（明治 $14 \cdot 23,1881 \cdot 1890$ 年）内国勧業博覧会

第 2 回・3 回の博覧会に関して本稿は, 概要を記すにとどめる。 明治 14 年の第 2 回内国博（図-8）では, 会場は第 1 回の売店 街の敷地にまで拡大され，そこには 4 つの本館が街区状に立ち並 んだ。寛永寺の中門は相変わらず残され, 旧本坊跡の敷地に従っ て柵がめぐらされていたが，その内部はコンドルの設計になる新 しい美術館 (博覧会後に完工して博物館となる) を正面に置き, 両 脇に農業・機械館を控えた, 構成としては先回同様に近代を指向 した計画であった。第 1 回内国博の一筆書き的な空間は消失し, そ れぞれの陳列館が等価均質に配置されるより近代性を帯びた空間 の意図が読みとれる。一方売店街はあくまでも「会場外」に位置 づけられながら, 門前から山下の広小路に近い黒門の外まで売店 街は拡大された。このように第 1 回の計画思想が継続されている ことが判る。(図-9）しかし空間構成全体としてみると寛永寺 の構成していた中堂とその奥の本坊からなる敷地がそれぞれ本館, 美術館等に置き換わった, 門前街も含めて寺院の空間構成を踏襲 した奥性の強い伝統的空間が色濃く反映されており, 最奥に位置 づけられる美術館は開催地を変えた第 4 回 (明治 29 年京都) や 5 回(明治 36 年大阪)の内国博にまで受け継がれることになる。 ${ }^{26)}$ なお美術館前の庭園は建物敷地が拡大された分, 先回の幾何式庭 園は削られている。案内書によれば庭園は愛知産の陶器を縁石と

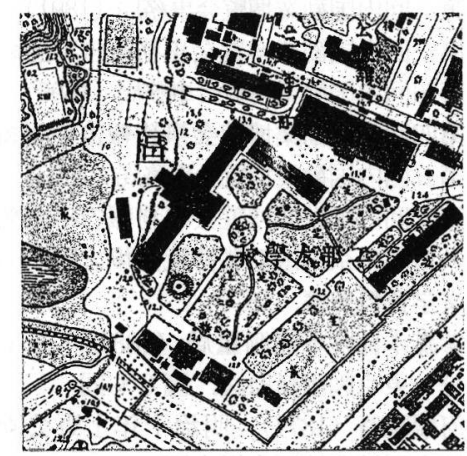

図-5 工部大学校 ${ }^{33}$



図-6 東京裁判所 ${ }^{33)}$

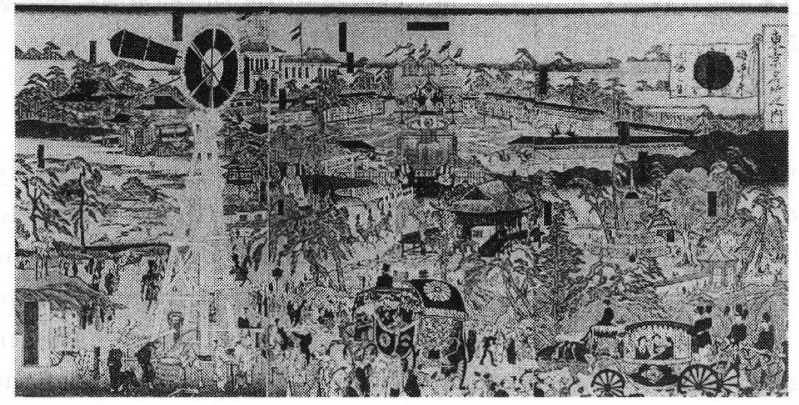

図－７明治十年上野公園地内国勧業博覧会場之図 ${ }^{34)}$

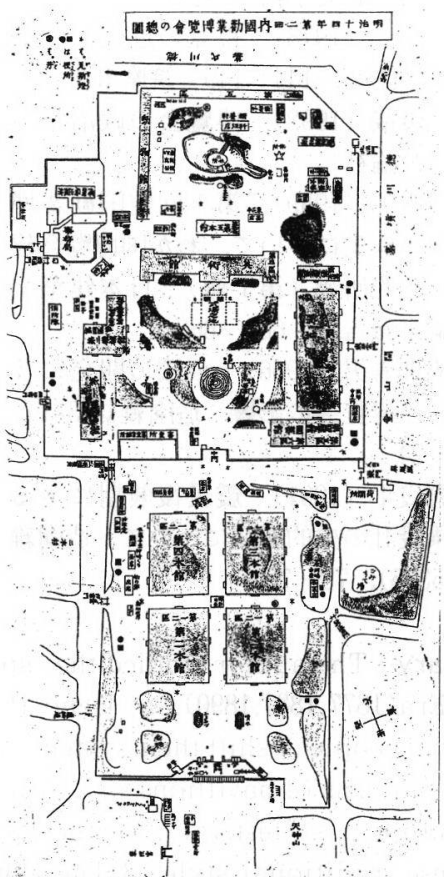

図－８第二回内国勧業博覧会平面図 ${ }^{35)}$ 


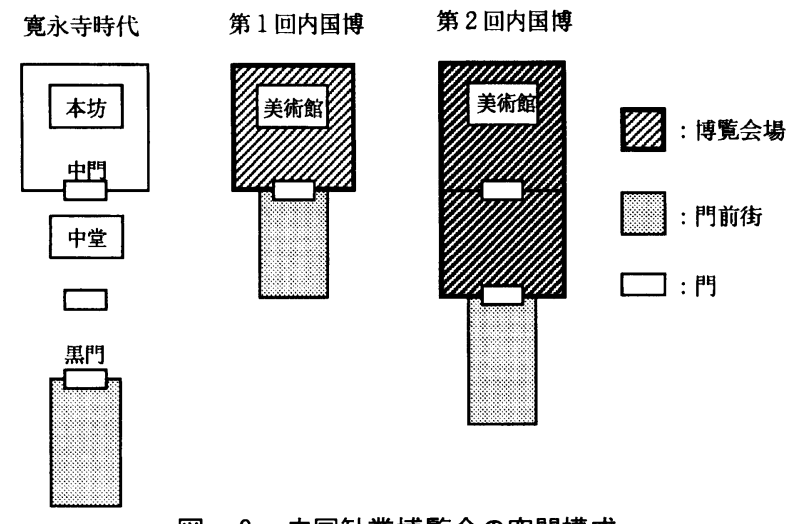

図-9 内国勧業博覧会の空間構成

した，芝生に国内外の草木花実を植え込んだ花壇状のもので, ${ }^{27)}$ 和洋折襄というべきスタイルである。

明治 23 年の第三回内国博は，会場内の建物配置や会場外の売 店に関しては第 2 回とほとんど変化はない。年) 会場デザインの基 本的思想は変わっていないと考えられる。しかし第 2 回の美術館 は博物館として常設の施設となって（明治 15 年）既に博覧会の 施設ではなくなり，一方会場の外では既に動物園（明治 15 年） や競馬場（明治 17 年）か開設されていた。この頃から上野は博 覧会によってもたらされた虚構性が，より恒常的な上野という界
隈の性格に変容しつつあったと考えられる。この点に関してはさ らに今後の検討を要するが，博覧会自身について見ても，門前の 売店街は，第 4 回，第 5 回内国博においては会場外の売店に加え てさらに会場内に飲食店等が入り込んでいき, ${ }^{30311}$ 博覧会は娛楽 的性格を主とするものに变質して行く。

4. おわりに

以上，明治前半期に東京上野公園で政府主催で開かれた内国勧 業博覧会場の空間計画思想の特質を考察した。明らかとなった点 は以下のように整理できる。

1)博覧会場においては近代的認識眼を重視する主催者の教化的意 図のもとに，近代を意味付けする西欧的空間配置が計画された。 2)同時に博覧会に祝祭的性格を付与する意図のもとに，縁日的空 間が会場外の門前に配置され，全体として相互補完的な都市的虚 構を形成することが計画された。

3）しかし会場全体の空間構成や，建物配置や庭園等のデザインに おいて近代的空間と伝統的空間が混在，交錯する場となった。

本稿では博覧会の計画に実際に携わった人物にまでは特に着目 しなかった。また本稿は当然ながら上野及び上野公園における博 覧会という土地側の側面と, その後の日本での博覧会という事業 側の側面においてそれぞれさらに考察を進める基礎となるもので あるが，これらの課題に関してはまた他日を期したい。

\section{参考文献及び補注}

1) 小林安茂 (1980)：上野公園，38-42： 郷学舎

2 ) 前嶋康彦 (1960)：東京公園史話その 十四 : 都市公園 No.23，25-29

3 ）田中正大（1974）：日本の公園：鹿島 出版会

4 ）樋口忠彦 (1985): 上野の山の場所の 意味：江戸とは何か 5 , 江戸東京学, 115-126: 至文堂

5 ) 陣内秀信, 伊藤一男（1985）：上野と 博覧会 : 歴史手帖 9 月号

6 ) 多木浩二 (1978) : 視覚の近代 : 明治 大正図誌 2，144-149：筑摩書房

7 ) 吉見俊哉（1992）：博覧会の政治学： 中央公論社

8 ）菊池重郎（1959）: 第 1 回内国勧業博 覧会の建築について，わが国博覧会建 築の史的研究（第 1 報）：日本建築学 会論文報告集, $665-668$

9 ) 高橋理喜男 (1966)：公園の開発に及 ぼした博覧会の影響 : 造園雑誌 3(1), $12-24$

10）小野良平 (1991）：震災復興期に至る 公園設計の史的展開について：造園雑 誌 53(5), 73-78
11）吉田光邦（1985）：改言丁版万国博覧会： 日本放送出版協会

12）明治十年内國勧業博覧会場案内：内國 勧業博覧会事務局, 1877

13）明治十年内國勧業博覧会場案内 改正 増補 : 内國勧業博覧会事務局, 1877

14）明治十年内國勧業博覧会規則帖：1876

15）澳國博覽會参同紀要 : 明治前期産業発 達史資料 第 8 集(2)：明治文献資料刊 行会, 1964

16）墺國博覧会筆記巻一，二，付図 : 1873

17）公文録，内務省之部明治十年四月内務 省同三には博覧会の出品量が予想より も多く，建築費が二倍にも増したとい うことが記されている。

18）工学会編（1927）: 明治工業史建築篇, p170 では外国人建築家によるものと 区別して営繥局員によるあのと記され ている。

19）越野武（1979）：日本の建築明治大正 昭和 $1 ・$ 開化のかたち, p123 : 三省 堂では工部省の林忠恕によるとされて いる。

20）藤森照信(1993）：日本の近代建築・上, $161-169$ : 岩波書店

21）前掲書 18), p170
22）堀越三郎（1929）：明治初期の洋風建 築, p154：丸善では外国人の設計を 示唆している。

23）前掲書 13), p1-6

24）前掲書 13), p17-18

25）明治十四年第二回内国勧業博覧会場獨 案内 : 山本義俊編, 1881

26）前掲論文 10)

27）前掲書 25), p23

28）井上安治（1881）: 第二回勧業博覧会 一覧

29）第三回内国勧業博覧会事務局（1891）: 第三回内国勧業博覧会事務報告平面図

30）第四回内国勧業博覧会事務局（1896）: 第四回内国勧業博覧会事務報告平面図

31）第五回内国勧業博覧会事務局（1903）: 第五回内国勧業博覧会事務報告平面図

32）大日本東京内国勧業博覧会場之図 : 国 文学資料館蔵, 1877

33）参謀本部陸軍部測量局（1887）：五下 分一東京図測量原図，図 6 6同

34）河鍋暁斎（1877），明治十年上野公園 地内国勧業博覧会場之図

35）第二回明治十四年内国勧業博覧会場案 内：内国勧業博覧会事務局, 1881

Summary: The author studied the spatial design concepts of three National Exhibitions which were held in the early Meiji Era (1877,1881,1890), at Ueno Park in Tokyo. The following facts were revealed. 1) Meiji-Goverment aimed to enlighten people to shift their system of perception for the World, so they designed the exhibition-sites (especially for the layout patterns of pavillions or garden design) in Western symmetrical style. 2)They also recognized the exhibition (exposition) as "festival", so they planned to build the market places in front and outside of the entrance-gates in Japanese traditional style. 3) The exhibition-sites were designed basically in Western style, but unconsciously, the traditional Japanese aspects of space-design appeared on the sites. 